\title{
INFLUENCE EARNING QUALITY AND LIQUIDITY OF COST OF CAPITAL
}

\author{
Nanik Lestari' ${ }^{1)}$, Umi Rahayu ${ }^{2)}$ \\ Accounting Department, Politeknik Negeri Batam \\ J1. Ahmad Yani, Batam Centre, Batam 29461, Indonesia \\ 1)E-mail: umirahayu8128@gmail.com \\ 2)E-mail: nanik@polibatam.ac.id
}

\begin{abstract}
This study was conducted to investigate the effect of earnings quality and liquidity of the capital costs. To measure earnings quality is done by using Discretionary Accrual using modified Jones models (Dechow et al, 1995), while liquidity is measured using liquidity risk. The sample used in this study was 290 company listed on the Indonesia Stock Exchange in 2010-2014, using simple regression to determine the effect of earnings quality and liquidity of the capital costs. Based on the results of the hypothesis in this study, showing that (1) the quality of earnings significantly negative effect on the cost of capital, (2) liquidity no significant effect on the cost of capital, (3) control variables used are not effect information asymmetry towards the cost of capital.
\end{abstract}

\section{Keywords: earning management, cost of capital, liquidity.}

\section{Introduction}

Profit (income) represents the difference between the income (revenue) minus costs (expense) of the business activities acquired during a certain period [8]. The resulting earnings quality companies influence the reaction of investors in investment (Cho and Jung, 1991). High earnings quality show that investors are interested in the earnings information Molaei et al, (2012). Information earnings reported by the company's management will be used by investors to invest funds in the decision making or forecast earnings in the future.

Investors buy stocks when they believe that profits in the future Can to increase the stock price (Robert et al, 2008). As corporate profits increase, the profit of the company can be said to be qualified [15].

Earnings quality can be affected by several factors, namely: systematic risk or beta, firm size, earnings persistence, earnings growth, capital structure, quality auditor, liquidity, and the quality of accruals [1]. Liquidity indicates that the company is able to meet the obligations for short-term use of current assets available. However, if the liquidity within a larger company, then the company meant not being able to manage its current assets as possible to show the performance in the company's poor and the possibility of manipulation of earnings information in the financial statements are used as information for the user. Gharezi and Zadeh (2013) says that liquidity has a negative correlation to the quality of earnings.

Past research Hsu and Yu (2015) demonstrate empirically that the quality of earnings, liquidity is one of the factors that affect the cost of capital. Hsu and Yu (2015) examine the effect of earnings quality, liquidity against capital costs. The result found that the three indicators of positive discretionary accruals related to the cost of equity capital. The results showed that the three indicators of positive discretionary accruals 
related to the cost of equity capital.

Bhattacharya (2010), which examines the relationship of earnings quality, information asymmetry on the capital costs of using the analysis of direct and indirect pathways mediated by information asymmetry. The result shows that there is a relationship between the quality of earnings with the cost of capital. Bhattacharya et al, (2013) showed that low earnings quality is highly correlated to the asymmetry of information, thus making the cost of capital is higher. Earnings quality is measured using the model proposed by Dechow et al (1995), including total discretionary accruals abnormal (ATDA), abnormal current discretionary accruals (ADCA), and long-term abnormal discretionary accruals (ADLA) as a measure.

Ifonie (2012) conducted a study on the effect of earnings management on the cost of equity capital. The results of the study showed no effect of earnings management on the cost of equity capital. Earnings management is calculated by discretionary proxy accuals also produce data not significant to the cost of equity capital. That is because investors assessed at the time of the issuer or the Vendor issuing new ordinary shares is to cover the operational and investment loans, so that the Vendor less attractive to investors.

Utami (2005) examined the effect of earnings management towards the cost of capital in the public company sector moderate variable beta stocks and market capitalization. Earnings management proxied by the ratio of working capital accruals with sales results from the research is that the earnings management and significant effect on the cost of capital, which means that the higher accrual rate, the higher the cost of capital.

In this study, the authors replicate research and $\mathrm{Yu}$ Hsu (2015) to reexamine the influence of earnings quality and liquidity of the cost of equity for companies listed on the Indonesia Stock Exchange. The author chooses the quality of earnings as a measure of the asymmetry of information for some reason that earnings quality is the price, relative to the components of cash flow from earnings, accrual accounting is more susceptible to management discretion and manipulation implies a less personal information. Earnings quality is measured using a three-factor model by Fama and French (1993) and modified Jones Model to estimate discretionary accruals as a proxy then separating nondiscretionary accrual (the rate of profit accrual reasonable) and discretionary accruals (rate of accrual earnings are not normal) in evaluating the quality profit management.

The motivation of this study was to determine whether investors in the Jakarta Stock Exchange has anticipated accrual information presented in the financial statements of the issuer. The reason the author is interested to assess the cost of equity capital is due to the cost of equity capital is the discount rate that is used by investors to assess tuna cash flows to be received in the future.

\section{Theoritical}

\section{Information asymmetry Theory}

Asymmetry of information is the imbalance of information between managers and shareholders or other stakeholders, where managers are more aware of internal information and the company's prospects in the future compared to the shareholder [12]. The smaller the asymmetry of information that occurs between managers and shareholders or other stakeholders, the less the cost of equity capital is borne by the company [12].

\section{Earning Management Theory}

Copeland (1968) defines as earnings management, "some ability to Increase or Decrease Reported net income at will". This means that the earnings management businesses include the management to maximize or minimize income, including income smoothing in accordance with the wishes of management. Earnings management is done by the company's managers to manipulate earnings to be higher, lower or always the same during some periods. Earnings management is management intervention in the process of preparing accounting profit in accordance with the interests of the management practices [16].

Profit is the result of a period that has been 
achieved by the company as defined in Statement of Financial Accounting Standarts (SFAS) (Suwardjono, 2010), the profit is one of the potential information contained in the financial statements and are essential for internal and external parties of the company, to do an assessment of earnings power of companies in the future.

\section{Cost of Equity}

According Sartono (2010), the cost of capital is the amount of costs to be incurred or to be paid to capital both derived from debt, preference shares, common stock, or retained earnings to finance the company's investment. The cost of capital is considered especially important in long-term investment decisions. Cost of equity can be calculated via a weighted average of several components of capital seen from the right side of the balance sheet (balanced sheet) which describes the long-term debt, preference shares (prefffered stock), common shares (common stock) and earnings (retained earnings) [12]. The cost of long-term debt is the cost of debt after taxes today to obtain long-term funding through loans. Cost of preferred stock is the annual dividend divided by the stock peferen the sale of preferred stock.

\section{Literature review}

\subsection{Effect of the quality of earnings towards the cost of capital}

Bhattacharya et al (2012) found a positive relationship between the quality of earnings and the cost of equity. The study shows that earnings quality and liquidity of individuals affect the cost of equity. Bhattacharya et al (2012), involves analysis of the direct and indirect relationships between three measures of quality of earnings and the cost of justice. Bhattacharya et al (2012) define the analytical model that directly and indirectly by the information asymmetry that consists of components election bid-ask spread and PIN (probability trade information). They found significant evidence of the direct path of the quality of earnings and indirect pathways of information asymmetry.
Results Hsu and Yu (2015) found that three indicators of discretionary accruals (accrual total discretionary abnormal (ATDA), abnormal discretionary current accruals (ADCA), and abnormal discretionary long-term accruals (ADLA)) were positively associated with significant cost of equity capital, especially for the long term and total accruals. The sample used 943 companies excluding finance and insurance industry in Taiwan on tahunn 2000-2011. The results of the study provide empirical evidence that earnings management and significant positive effect on the cost of equity capital.

Utami (2006) examined the effect of earnings management on the cost of equity capital in public companies manufacturing sector by moderating variable beta stocks and market capitalization. Earnings management proxied by the ratio of working capital to sales accruals. Results of research Utami (2006) showed that the positive effect on the earnings management cost of equity capital, this case shows that the greater the earnings management performed by the manager, it will increase the cost of equity capital.

Francis et al (2004) examined the relationship between attributes of earnings and the cost of equity. In this study, attribute profit includes accrual quality, persistence, smoothness, value relevance, timeliness, and concert-vatisme, while the cost of equity is indakator investor resource allocation decisions. Results Francis et al (2004) showed that companies with earnings that have the attributes unfavorable earnings have higher capital costs than companies that have the attributes of a profitable return. Results of research Francis et al (2004) showed that the quality of earnings has the role of lowering the cost of equity. The higher the quality of profits, the lower the cost of equity.

Ifonie (2012) states that the information asymmetry and earnings management does not affect the cost of equity capital 29 real estate companies listed on the Indonesia Stock Exchange in the period 2007-2009. Ifonie (2012) explains that investors assess at this time, issuers or companies that issue new ordinary shares is to cover the operational and investment loans, so the company less attractive to 
investors. So voluntary disclosures made by the company do not affect ith the magnitude of the cost of equity capital issued by the company.

Purwanto (2008) investigated the earnings management, assimetri information, and voluntary disclosure of the cost of capital. According to analysis carried out by using a sample of 18 companies listed on the Stock Exchange 2005-2007 period. Purwanto research results (2008) show that earnings management does not affect the cost of capital (cost of equity), this shows that the cost of capital will not increase with increasing earnings management.

\subsection{Effect of the liquidity of the capital costs}

Deng and Ong (2014) examined the effect of lkuiditas towards the cost of capital. Deng and Ong, (2014) found the managers manipulate earnings management during the period of the capital increase the company to attract uninformed investors, thereby increasing liquidity. CAPM (Capital Asset Pricing Model) based on the adjusted liquidity is another to test the liquidity risk of the stock price or return. Deng research results and Ong (2014) shows that companies with less liquid so may manipulate income before equity deals.

Acharya and Pedersen (2005) suggest that the stock returns that are required depends on the expected liquidity and the covariances of return and liquidity to the market return. Therefore, the impact of liquidity on stock returns are not assured. Acharya and Pedersen (2005) investigated 48 developed countries and developing countries around the world. He found that a variety of liquidity risk arising from covariances of return on assets (liquidity) with local and global markets is the price. However, liquidity risk is also influenced by the geographic, economic and political, particularly for developing countries.

Hsu and Yu, (2015) found that the volume of trade and capital costs showed a significant positive relationship while a negative relationship between liquidity risk of individual stocks and the cost of capital. In the trading volume and liquidity risk, if the liquidity and liquidity risk is high, the cost of equity is low if the low level of information. The results of Hsu, and $\mathrm{Yu}$ (2015) confirms managers need to fully disclose information to reduce capital costs.

\section{Hypothesis Development}

\subsection{Impact Earning Quality of Cost of Equity}

Stolowy and Breton (2000) in the study (Utami, 2005) describes manipulating earnings account solely based on management's desire to influence the perception of investors on the company's risk. The risks can be divided into two components, namely: first, the risks associated with variations in yield as measured by earnings per share (earnings per share). Secondly, the risks associated with the company's financial structure, as measured by debt equity ratio. Therefore, the higher the level of earnings quality manunjukan the higher the risk of stock returns and consequently the results of investors will increase the cost of capital rate.

Bhattacharya et al (2012) found a positive relationship between the quality of earnings and the cost of equity. The study shows that earnings quality and liquidity of individuals affect the cost of equity. Bhattacharya et al (2012), involves analysis of the direct and indirect relationships between three measures of quality of earnings and the cost of justice. Bhattacharya et al (2012) define the analytical model that directly and indirectly by the information asymmetry that consists of components election bid-ask spread and PIN (probability trade information). Bhattacharya et al (2012) found significant evidence of the direct path of the quality of earnings and indirect pathways of information asymmetry.

Utami (2006) menguji pengaruh manajemen laba terhadap biaya modal ekuitas pada perusahaan publik sektor manufaktur dengan variabel moderasi beta saham dan kapitalisasi pasar. Manajemen laba diproksi berdasarkan rasio akrual modal kerja dengan penjualan. Hasil penelitian Utami (2006) menunjukkan bahwa manajemen laba berpengaruh positif terhadap biaya modal ekuitas, hal Ini menunjukkan bahwa semakin besar manajemen laba yang dilakukan oleh 
manajer, maka akan meningkatkan biaya modal ekuitas.

Hsu and Yu (2015) found that three indicators of discretionary accruals positively influence the cost of capital, particularly for long-term and total accruals. Based on the explanation, the research hypothesis is as follows:

H1: earnings quality affect the cost of capital (cost of equity).

\subsection{Impact Liquidity of Cost of Equity}

Acharya and Pedersen (2005) suggest that the stock returns that are required depends on the expected liquidity and the covariances of return and liquidity to the market return. Therefore, the impact of liquidity on stock returns are not assured. Acharya and Pedersen (2005) investigated 48 developed countries and developing countries around the world. He found that a variety of liquidity risk arising from covariances of return on assets (liquidity) with local and global markets is the price. However, liquidity risk is also influenced by the geographic, economic and political, particularly for developing countries.

$\mathrm{Hsu}$ and $\mathrm{Yu}$ (2015) find that the negative correlation between individual stocks liquidity risk and capital costs. In the trading volume and liquidity risk, if the liquidity and liquidity risk is high, the cost of equity is low if the low level of information. The results of $\mathrm{Hsu}$, and $\mathrm{Yu}$ (2015) confirms managers need to fully disclose information to reduce capital costs. Based on the explanation above it can be concluded hypotheses: $\mathrm{H} 2$ : Liquidity affect the cost of capital.

\section{Research Methods}

\subsection{Type and sources of data}

The population of this research are companies listed on the Indonesia Stock Exchange in the manufacturing sector during the 2010-2014 period. The sampling technique used purposive sampling, the sampling technique premises certain criteria, among others, manufacturing companies listed in Indonesia Stock Exchange (IDX) on tahun2010-2014, has a complete data associated with the variables needed, companies that do not suffer losses, and companies that use the value of currency.

\subsection{Variabel Operational}

\section{Earnings Quality}

The quality of earnings in this study is proxied by discretionary accrual. The calculation is done by calculating the total accrual earnings, then separating nondiscretionary accrual (accrual reasonable profit levels) and discretionary accrual (accrual earnings levels are not normal). The use of discretionary accrual is calculated with the modified Jones model (Dechow et al, 1995). Discretionary accruals (DA) dapatdihitung using:

DAit $=$ Tacit $/$ TAit - NDAit

\section{Liquidity}

Liquidity risk is the risk that arises when a company does not have the ability to pay its financial obligations. This study measures the liquidity of the company's stock liquidity proxies (LiRiskit). Market liquidity Estimate by Pastor and Stambaugh (2003), as follows:

LiRisk $=$ BAit $-\mathrm{m}($ BAit $)) / \mathrm{s}($ BAit $)$

\section{Cost of Capital}

These variables are proxies to measure how much it costs to raise capital. The cost of capital is measured by using abnormal return by adopting research of Fama and French (1993). Abnormal Return to the approach of market adjusted model, as follows:

$\mathrm{ABNit}=$ Rit $-\mathrm{E}[$ Rit $]$

Information :

$\mathrm{ABNit}=$ abnormal return of separation $\mathrm{i}$ at time $\mathrm{t}$

Rit $=$ actual return for stock $\mathrm{i}$ at time $\mathrm{t}$

$\mathrm{E}[\mathrm{Rit}]=$ expected return for stock $\mathrm{i}$ time $\mathrm{t}$

\subsubsection{Information Asymmetry}

Bid ask spread is used as a variable asymmetry of information using the model Bhattacharya et al (2012) which is calculated by the monthly stock price as follows:

Basit $=$ askprice - bidprice $/($ askprice + bidprice $) / 2 *$ $100 \%$

Information : 
Askprice $=$ highest stock price of firm $\mathrm{i}$ ask that occurred on day $\mathrm{t}$

Bidprice $=$ lowest bid price of the company stock that occurred on the day i $t$

Here is a regression equation used in this study:

$Y=\alpha+\beta 1 D A i t+$ Basit $+\varepsilon_{-}$it

$Y=\alpha+\beta 1$ LiRiskit + Basit $+\varepsilon \_$it

Information :

$\mathrm{Y}=$ Cost of capital

$\alpha=$ constants

$\beta 1=$ Regression Coefficients

DAit $=$ Discretionary Accrual

LiRiskit $=$ Risk Liquidity

BAS it $=$ Bid Ask Spread

\section{Result and Discussion}

\subsection{Sample}

The data used in this research is manufacturing companies listed in Indonesia Stock Exchange (BEI) in the period in 2014 which amounted to 155 companies. Total sample of 58 companies per year, so that in 2010-2014 with a total sample of 290 companies.

Table 6.1. Sample Calculation Results

\begin{tabular}{|c|c|}
\hline Indications Company & Total \\
\hline $\begin{array}{l}\text { Manufacturing companies listed in } \\
\text { Indonesia Stock Exchange Company } \\
\text { Number Indication }\end{array}$ & 155 \\
\hline $\begin{array}{l}\text { Companies that do not have the required } \\
\text { variables writer }\end{array}$ & (43) \\
\hline Companies that suffer losses & $(28)$ \\
\hline Companies that use foreign currencies & $(26)$ \\
\hline Companies selected as samples per year & 58 \\
\hline Total sample period of $2010-2014$ & 290 \\
\hline
\end{tabular}

\subsection{Descriptive Statistics}

Based on the test results of descriptive statistics in Table 1 it is known that there are 3 vaiabel research (DA, LIRISK, BAS). The dependent variable in this study is the cost of capital as measured by abnormal return $(\mathrm{ABN})$. The highest value (maximum) of
9.548611. The lowest value (minimum) of -1.000000 . The deviation between the values obtained between the actual return expected return can be seen in the value of the standard deviation, where the percentage of the value of the standard deviation of 1.539848 .

Table 6.2. Descriptive Statistics

\begin{tabular}{|c|c|c|c|c|}
\hline Var & Mean & Max & Min & S.D \\
\hline ABN & 0.487 & 9.549 & -1.000 & 1.54 \\
\hline DA & 0.575 & 11.554 & -9.486 & 1.36 \\
\hline LIRISK & 2.367 & 14.554 & -2.613 & 2.97 \\
\hline BAS & 3.146 & 49.547 & -2.613 & 5.78 \\
\hline
\end{tabular}

The first independent variable is the quality of earnings is measured using the accrual diskresioneri. The average value (mean) of all samples companies amounted to 0.574889 . The lowest value (minimum) -9.486537, this shows the company earning management by lowering profits. The independent variables were the second is liquidity using the liquidity risk ie where the company is unable to pay its debts. The average value of 2.367099 . The highest value of a maximum of 14.55399

The average value (mean) of the variable bid ask spread amounted to 3.146414 , the lowest value (minimum) of -2.613240 , and the highest value (maximum) of 49.54751. The deviation between the value of the information given to the managers of companies with investors can be seen from the standard deviation, where the percentage standard deviation value for the bid ask spread amounted to 5.780334 .

\subsection{Data Analysis \\ Impact Earning Quality of Cost Of Capital}

Based on the test results table 4.3 on the influence of the quality of earnings towards the cost of capital shows that earnings quality is measured using DA significant negative effect on the cost of capital in view of the significant value of 0.0102 ( $p$-value $<0.05$ ). Adjusted R-Square value in the table above shows that the variable cost of capital is affected by the independent variables, earnings quality and liquidity of 
$1 \%(0.016931)$ and the remaining $99 \%$ is influenced by other variables.

Tabel 4.3. Hasil Pengujian Hipotesis

\begin{tabular}{|c|c|c|c|c|}
\hline Var & Coef & t-Stat & Prob. & VIF \\
\hline DA & -0.171 & -2.588 & $0.0102 * *$ & 1.00315 \\
\hline BAS & -0.006 & -0.384 & 0.7013 & 1.00315 \\
\hline $\begin{array}{c}\text { Adjust } \\
\text { ed R }\end{array}$ & \multicolumn{3}{|c|}{0.016931} \\
\hline F-stat & \multicolumn{3}{|c|}{3.488661} \\
\hline $\begin{array}{c}\text { Prob(F } \\
\text {-stat) }\end{array}$ & \multicolumn{3}{|c|}{2.031843} \\
\hline Obs*R & \multicolumn{3}{|c|}{290} \\
\hline $\begin{array}{c}\text { Sampe } \\
\text { I (N) }\end{array}$ & \multicolumn{3}{|c|}{${ }^{*} p<0.1, * * P<0,05, * * * P<0.01$} \\
\hline Sig &
\end{tabular}

Test Multicollinearity with VIF indicates that there is no multikolineartis between the variables used in the testing H1 (10.00> VIF>0:10). p-value at obs * r-square of 2.441878 obtained from white test also showed that the data used is not heteroskedatisitas (p-value $>0.05$ ). The results are consistent with research conducted by Francis et al (2004) that the quality of their earnings negatively affect the cost of capital. Results of research Francis et al (2004) showed that the quality of earnings has the role of lowering the cost of equity. The higher the quality of profits, the lower the cost of equity.

H1. Earnings Quality Negative effect on the Cost of Capital.

\section{Analysis of Effect on the Cost of Capital Liquidity}

Based on the test results table 4.4 on the effect of liquidity on the capital cost of the sample 290 manufacturing companies in Indonesia dilkukan with Eviews 7.0 program. Based on the results of Hausman test this hypothesis using a random effect model, as can be seen prob value $>0.05$ then use a random effect model.

Table 4.4. Hypothesis Testing Results

\begin{tabular}{|c|c|c|c|c|}
\hline Var & Coef & t-Stat & Prob. & VIF \\
\hline LiRisk & 0.026 & 0.619 & 0.5362 & 1.4066 \\
\hline BAS & -0.016 & -0.754 & 0.4513 & 1.4066 \\
\hline $\begin{array}{c}\text { Adjusted } \\
\text { R }\end{array}$ & \multicolumn{4}{|c}{0.171798} \\
\hline F-stat & \multicolumn{4}{|c}{0.808642} \\
\hline
\end{tabular}

\begin{tabular}{|c|c|}
\hline $\begin{array}{c}\text { Prob(F-sta } \\
\mathrm{t})\end{array}$ & 0.832617 \\
\hline Obs*R & 1.333519 \\
\hline $\begin{array}{c}\text { Sampel } \\
(\mathrm{N})\end{array}$ & 290 \\
\hline Sig & ${ }^{*} \mathrm{p}<0.1,{ }^{* *} \mathrm{P}<0.05,{ }^{* * *}<0.01$ \\
\hline
\end{tabular}

Multicolinearity test with VIF indicates that there is no multikolineartias between the variables used in the test $\mathrm{H} 2(10.00>\mathrm{VIF}>0: 10)$. p-value at obs * r-square of 1.333519 obtained from white test also showed that the data used is not heteroskedastisitas (p-value $>0.05$ ). From the results table shows that the Liquidity Risk Liquidity is measured using not significant effect on the cost of capital in view of the significant value of 0.5362 (p-value $>0.05$ ).

The results are consistent with research conducted by the Acharya and Pedersen (2005) found that the impact of liquidity on stock returns are not assured. He found that a variety of liquidity risk arising from covariances of return on assets (liquidity) with local and global markets is the price. H2. Liquidity does not affect the cost of capital.

\section{CONCLUSION}

\subsection{Resume}

Based on the results of research on the effect of earnings quality and liquidity of the capital costs. This study used a sample of companies manuaktur as many as 58 companies a year and as many as 290 companies from 2010-2014.

The results showed that the quality of earnings negatively affect the cost of capital, which illustrates that in companies with earnings that are not profitable can increase investors in investing to make the cost of capital is higher than the company had a profitable return. Effect of liquidity to capital costs showed that the liquidity variables do not affect the variable cost of capital because due to liquidity risk arises if the company is unable to pay its debts, while companies that pay its debts by using the price of the stock market does not affect the cost of capital, could have been in debt servicing companies use asset .

\section{2. implication}

The implications of this research aimed at manufacturing companies in Indonesia about how to maintain a quality earnings in order to influence the reaction of investors in the investment. Additionally, earnings information reported by the company's management will be used by investors to invest in the $\mathrm{ke} \neg$ putusan decision to increase the capital. 


\section{3. limitation}

This study has a limitation that only uses the independent variable (earnings quality and liquidity) and dependent (cost of capital) equal to research and yu Hsu (2015). The study also only use a sample of manufacturing firms in the year 2010-2014, so the results of this study can not be applied to companies other than companies manufacturing such as financial sector companies.

\section{Daftar Pustaka}

[1]Astika, K. P. (2014). Pengaruh, Likuiditas, Pertumbuhan Laba, dan Ukuran Perusahaan pada Kualitas Laba. E-Jurnal Akuntansi Universitas Udayana, 64-78.

[2]Atmaja. (2008). Teori dan Praktik Manajemen Keuangan. Jakarta: ANDI Yogyakarta.

[3]E.Copeland, J. W. (2010). Manajemen Keuangan. Tangerang: Binarupa Aksara.

[4]Ghozali, I. (2012). Aplikasi Analisis Multivariate dengan Program IBM SPSS 20. Semarang: Universitas Diponegoro.

[5]Hartono, D. Metodologi Penelitian Bisnis. Yogyakarta: bpfe.

[6]Hsu, M.-F., \& YU, J. (2015). Theiinfluence of Earnings Quality and Liquidity on the Cost of Equity. International business research, 8, 194-209.

[7]Ifonie, R. R. (2012). Pengaruh Asimetri Informasi dan Manajemen Laba Terhadap Cos of Equity Capital pada Perisahaan Real Estate yang Terdaftar di Bursa Efek Indonesia. Jurnal Ilmiah Mahasiswa Akuntansi, 1, 103-107.

[8]Islahuzzaman. (2012). Istilah-Istilah Akuntansi \& Auditing. Jakarta: Bumi Aksara.

[9]Islam, M. A. (2011, Mei). Is Modified Jones Model Effective in Detecting Earnings Management? International Journal of Economics and Finance, 3, 116-125.

[10]Munawarah. (2009). Analisis perbandingan abnormal return dan trading volume activity sebelum dan setelah suspend bei. Semarang.

[11]Novianti, r. (2012). Kajian kualitas laba pada perusahaan manufaktur yang terdaftar di bei. Accounting analysis journal, 1-26.
[12]P.Tampubolon, Manahan. (2013). Manajemen Keuangan. Jakarta: Mitra Wacana Media.

[13]Purwanto, A. (2008). Pengaruh Manajemen Laba,Asymmetry Information dan Pengungkapan Sukarela terhadap Biaya Modal.

[14]Sartono, A. (1999). Manajemen Keungan. Yogyakarta: BPFE Yogyakarta.

[15]Siallagan, H. (2006). Mekanisme Corporate Governance, Kualitas Laba dan Nilai Perusahaan. Simposium Nasional Akuntansi, $1-17$.

[16]Sulistyanto, S. (2002). Manajemen Laba ,Teori dan Empiris. Jakarta: Grasindo.

[17]Suliyanto. (2009). Ekonometrika Terapan: Teori dan Aplikasi dengan SPSS. Yogyakarta: Andi.

[18]Susanto, S. (2009). Corporate Governance, Kualitas Laba, dan Biaya ekuitas : Studi Empiris Perusahaan Mnaufaktur yang Terdaftar di Bursa Efek Indonesia Tahun 2009. Jurnal Universitas Indonesia, 1-28.

[19]Suwardjono. (2010). Teori Akuntansi : Perekayasaan Pelaporan Keuangan. Yogyakarta: BPFE.

[20]Usman, N. D. (2006). Pendekatan Populer dan praktis Ekonometrika untuk Analisis Ekonomi dan Keuangan. Jakarta: Fakultas Ekonomi Umiversitas Indonesia.

[21]Utami, W. (2005). Pengaruh Manajemen :aba Terhadap Biaya Modal Ekuitas. SNA8, 100-116. 